

Mound Laboratory Chemistry and Physics Progress Report: January-March 1971

November 15,1971

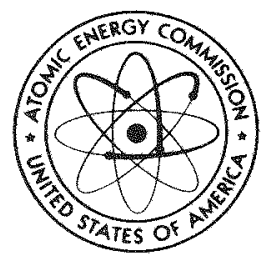

AEC Research and Development Report

MOUND LABORATORY

Miamisburg, Ohio

operated by

Monsanto

MONSANTO RESEARCH CORPORATION a subsidiary of Monsanto Company for the

U. S. ATOMIC ENERGY COMMISSION

U. S. Government Contract No. AT-33-1-GEN-53 


\section{DISCLAIMER}

This report was prepared as an account of work sponsored by an agency of the United States Government. Neither the United States Government nor any agency Thereof, nor any of their employees, makes any warranty, express or implied, or assumes any legal liability or responsibility for the accuracy, completeness, or usefulness of any information, apparatus, product, or process disclosed, or represents that its use would not infringe privately owned rights. Reference herein to any specific commercial product, process, or service by trade name, trademark, manufacturer, or otherwise does not necessarily constitute or imply its endorsement, recommendation, or favoring by the United States Government or any agency thereof. The views and opinions of authors expressed herein do not necessarily state or reflect those of the United States Government or any agency thereof. 


\section{DISCLAIMER}

Portions of this document may be illegible in electronic image products. Images are produced from the best available original document. 
MLM- 1815

TI D -4500

UC -4 and UC -34

\section{Mound Laboratory Chemistry and Physics Progress Report: January-March 1971}

Is sued: November 15, 1971

\section{NOTICE}

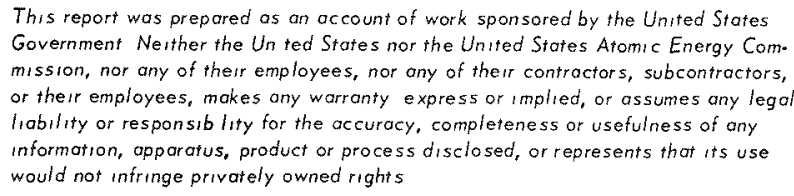

This report was prepared as an account of work sponsored by the United States Government Nerther the Un ted States nor the United States Atomic Energy Com mission, nor any of their employees, nor any of their contractors, subcontractors, or their employees, makes any warranty express or implied, or assumes any legol liability or responsib lity for the accuracy, completeness or usefulness of any information, apporatus, product or process disclosed, or represents that its use would not infringe privately owned righis

$$
\begin{gathered}
\text { PRINTED IN THE UNITED STATES OF AMERICA } \\
\text { Avalable from } \\
\text { Nationaf Technical information Service } \\
U S \text { Department of Commerce } \\
5285 \text { Port Royal Road } \\
\text { Springf eld } V \text { rg nfa } 22151 \\
\text { Price Printed Copy } \$ 300 \text { Microfiche } \$ 095
\end{gathered}
$$

MONSANTO RESEARCH CORPORATION

A Subsidiary of Monsanto Company

\section{MOUND LABORATORY}

Miamisburg, Ohio

45342

operated for

\section{UNITED STATES ATOMIC ENERGY COMMISSION}

US Government Contract No AT-33-1 GEN-53 


\section{Foreword}

The Mound Laboratory Chemistry and Physics Progress Report, issued quarterly, is intended to be a means of reporting items of current technical interest in research and development programs. Since this is an informal progress report, the results and data presented are preliminary and subject to change.

These reports are not intended to constitute publication in any sense of the word. Final results either will be submitted for publication in regular professional journals or will be published in the form of MLM topical reports. Questions concerning the material compiled here should be directed to W. T. Cave, Director, Nuclear Operations.

Previous reports in this series are:

MLM -1792

MLM -1767

MLM-1751

MLM-1726
MIM-1612

MLM-1609

MLM-1606

MIM-1603 


\section{Table of Contents}

$\underline{\text { Page }}$

SEPARATION CHEMISTRY

Residue Adsorption. ...................... 5

The adsorption of polonium-210 on noble metal surfaces appears to be a combination of physisorption and chemisorption, strongly suggestive of the catalytic reduction of polonium. The degree to which the polonium can be desorbed is dependent on both the nature and the recent history of the metal surface.

Thorium-229 Recovery. . . . . . . . . . . . . . .

Three uranium-thorium separation runs were completed on a total of approximately $190 \mathrm{~g}$ of uranium-233. This resulted in the recovery of $6 \mathrm{mg}$ of pure thorium-229, of which $4 \mathrm{mg}$ have been prepared for shipment.

Airport Cake Residues ........................

The St. Louis Residues are being processed by the Cotter Corporation of Canon City, Colorado, and Mound Laboratory is studying the feasibility of recovering protactinium-231 and thorium-230 from the cotter process. A new set of process samples was received and analyzed. A method of recovering both protactinium and ionium is being developed.

\section{INORGANIC CHEMISTRY}

A New Samatium Hydride. . . . . . . . . . . . . . . .

A new hydride of samarium has been prepared by dissolving samarium metal in warm, dilute acetic acid. X-ray powder patterns of the compound were obtained. This material might serve as a starting material for the preparation of samarium (II) oxide. 
Entropy terms constituting Planck Functions for uranium, neptunium and plutonium ions are plotted. The disproportionation reactions of the ions of these elements are discussed.

\section{ANALYTICAL CHEMISTRY}

Determination of Plutonium in Soi1 . . . . . . . . . . . . . 18

Four soil samples and a standard have been analyzed for plutonium by a fusion method. Errors and blank determinations, as we11 as relative plutonium concentrations, are given.

Evaluation of the Portable Gamma-Measuring Technique for

Determining Plutonium-238 in Gloveboxes. . . . . . . . . . . .

The portable-gamma-monitor method presently employed for determining plutonium-238 in terminated gloveboxes is being evaluated to determine the reliability of its results. The evaluation, consisting of a cross-comparison of results of portable-gamma-monitor assay, can assay and cratedhood assay, indicated significant biases between the methods. A more precise technique of plutonium-238 determination and more reliable instrumentation are being investigated to rectify the problem.

\section{NUCLEAR PHYSTCS}

Spontaneous Fission Half-Life of Plutonium-238 . . . . . . . . 26

The spontaneous fission half-life of $238 \mathrm{Pu}$ has been measured using silicon surface barrier detectors and commercially available electronic equipment to detect the fission fragments. A value of $(4.77 \pm 0.14) \times 10^{10} \mathrm{yr}$ was obtained from two foils of different isotopic compositions.

REFERENCES . . . . . . . . . . . . . . . . . . . . . . . 


\title{
Separation Chemistry
}

\author{
RESIDUE ADSORPTION
}

The adsorption of polonium-210 on noble metal surfaces appears to be a combination of physisorption and chemisorption, strongly suggestive of the catalytic reduction of polonium. The degree to which the polonium can be desorbed is dependent on both the nature and the recent history of the metal surface.

For example, gold and platinum foils were ignited at $900^{\circ} \mathrm{C}$. After they were cooled to room temperature, one drop of polonium-210 in $1 \mathrm{~N}$ HC1 solution was deposited on each foil and evaporated to dryness at $95^{\circ} \mathrm{C}$. Each foil was washed with $1 \mathrm{~N}$ HCl; the gold foil retained $2.0 \%$ and the platinum foil retained $98.7 \%$ of the original polonium. On the other hand, a platinum foil which had previously been soaked in $6 \mathrm{~N} \mathrm{HCl}$ at $90^{\circ} \mathrm{C}$ for 16 hr retained only $65.1 \%$ of the polonium subsequently deposited on it.

To test the possibility that the polonium was being reduced by base metal impurities in the platinum, a drop of polonium solution was deposited on each of two platinum foils previously ignited at red heat and cooled. Both foils were allowed to stand at room temperature: after $1 \mathrm{hr}$ the remaining solution on one foil was washed away with $1 \mathrm{~N}$ HC1. The foil retained on $1 \mathrm{y} 2.8 \%$ of the original polonium. After $1 \overline{7} \mathrm{hr}$ at room temperature, the solution on the second foil had evaporated to dryness. On being washed with $1 \mathrm{~N} \mathrm{HC}$, the foil retained $18.6 \%$ of the original polonium.

To study the adsorptive behavior of polonium on different metals, a standard cleaning procedure was adopted:

Each foil was soaked in alcoholic $\mathrm{KOH}$ for $10 \mathrm{~min}$ and rinsed thorough1y with distilled water. It was dried with absorbent paper and sprayed with Krylon Crystal Clear Spray Coating, except for a circular area $0.8 \mathrm{~mm}$ in diameter. The coating was allowed to dry at room temperature and the foil was placed on a hot plate regulated at $95^{\circ} \mathrm{C}$. The uncoated area was covered witn two drops of $6 \mathrm{~N} \mathrm{HCl}$ and heated for 1 min, after which it was rinsed with wate $\bar{r}$ and allowed to dry at $95^{\circ} \mathrm{C}$. One drop $(50 \mu 1)$ of $1 \mathrm{~N}$ HC1 
containing $\sim 0.5 \mu \mathrm{Ci}$ of $" 10$ Po was deposited in the uncoated area and evaporated to dryness at $95^{\circ} \mathrm{C}$. The residue was covered with $1 \mathrm{~N} \mathrm{NH}_{4} \mathrm{OH}$ and again allowed to dry at $95^{\circ} \mathrm{C}$. The foil was then a'pha-counted in a $2 \pi$ proportional counter.

The residue was covered with the selected desorption reagent, which was heated for $1 \mathrm{~min}$ at $95^{\circ} \mathrm{C}$ and removed. The desorption was repeated and the foil, after being allowed to dry, was again alpha-counted. The results, expressed as the percentage of the original alpha-counting rate remaining after desorption, are given in Table 1.

Table 1

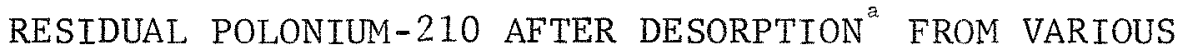
METAL SURFACES

Adsorbent Material

Desorbent

$0.01 \mathrm{~N} \mathrm{HC} 1$

$0.1 \mathrm{~N}$ HCI

1. ON HC1

3. $\mathrm{ON} \mathrm{HCl}$

$6.0 \mathrm{~N} \mathrm{HC1}$

IN $\mathrm{HNO}_{3}$

3N HNO.

\section{Platinum}

$-$

97.3

89.5

79.0

78.6

37.4

15.4

Go1d

$-$

96.8

79.6

47.9

16.7

Tantalum

73.5

40.8

$$
4.8
$$

56.5

47.8

36.3

- Values are given as percent of material not desorbed by the solvent.

Attempts to decontaminate the various foils with HCl and HNO were only partially successful. Even after $2 \mathrm{hr}$ in aqua regia, an iridium foil retained almost $2 \%$ of the original polonium. Reverse electrolysis, using a polonium-contaminated platinum foil as the anode, removed a 11 but $4 \%$ of the original polonium. 


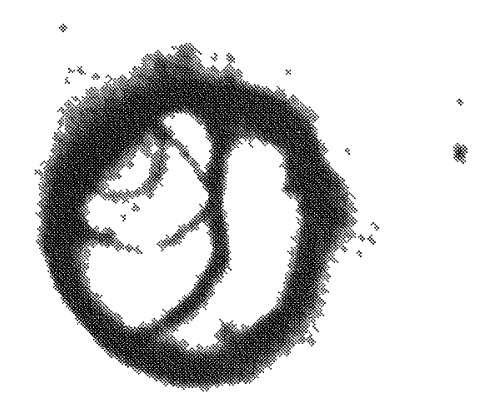

FIGURE 1 - Radioautograph of polonium-210 on an iridium foil。
Figure 1 is a radioautograph of an iridium foil which has been partially decontaminated with $6 \mathrm{~N}$ HC1 and $3 \mathrm{~N}^{-} \mathrm{HNO}_{3}$ but still rétains approximately $0.1 \mu \mathrm{Ci}$ of polonium-210. The diffuse background corresponds to the area in which the polonium was origina11y deposited; the intense lines correspond to its drying pattern. The significance of this pattern is difficult to interpret at the present time; the foil is now being sectioned to determine the depth of penetration of the polonium into the iridium surface. (H. W. Kirby)

\section{THORIUM-229 RECOVERY}

The uranium-thorium separation run which was started previously was completed with the recovery of $2.5 \mathrm{mg}$ of thorium-229 from a possible $2.7 \mathrm{mg}$. The recovered material was pooled with that from the previous run and the total of $4 \mathrm{mg}$ of thorium-229 is in a shipping container awaiting shipping instructions.

The run was made by the usual DSBPP (di-sec-butyl phenylphosphonate) uranium-thorium solvent extraction separation step, followed by cation exchange purification of the product. An initial attempt was made to do the separation and purification in one ion exchange step, using 1. $5 \mathrm{M} \mathrm{HNO}_{3}$ feed on $\mathrm{AG}-50 \mathrm{~W}$ XI2 cation exchange resin with $\mathrm{NH}_{4} \mathrm{C}_{2} \mathrm{H}_{3} \mathrm{O}_{2}-$ $\mathrm{HC}_{2} \overline{\mathrm{H}}_{3} \mathrm{O}_{2}$ elution, but the thorium did not load on the resin. The difficulty is believed to be caused by a trace of residual fluoride in the feed, even after additional fumings with concentrated $\mathrm{HNO}_{3}$. The residual fluoride could be complexed by the addition of $\mathrm{Al}\left(\mathrm{NO}_{3}\right)_{3}$, but this would have to be removed, after the separation, so that the uranium233 could be stored in non-diluted form. An additional solvent extraction step to do this would result in the same amount of processing as is done now.

Another separation run on $65 \mathrm{~g}$ of uranium-233 has been essentially completed with $2 \mathrm{mg}$ of pure thorium-229 recovered to date. Clean-up of the solutions and equipment is under way and some additional material is expected to be recovered. Solvent extraction was used for uraniumthorium separation in this run. (M. R. Hertz) 


\section{AIRPORT CAKE RESIDUES}

The Cotter Corporation of Canon City, Colorado has been processing the material known as "St. Louis Residues" for its uranium, copper, cobalt, and nickel values. Mound Laboratory is studying the feasibility of recovering protactinium-231 and thorium-230 (ionium) from the Cotter process.

The Cotter process has been described previous $1 y^{I}$ and the chemistry and the feasibility of recovering protactinium and ionium were discussed. ${ }^{2}$ However, process modifications were instituted several months after the initial sampling, and a new set of samples was obtained for analysis and evaluation. The new process consists of dissolution and separation of insoluble material, as before, but this is followed by a new step for selenium recovery. The solvent extraction step is next, followed by the precipitation and recovery of copper sulfide, and finally the recovery of a cobalt-nickel sulfide product. Descriptions of the ten new Cotter samples are listed in Table 2.

Aliquots of the new samples were transferred to plastic vials and their gamma spectra were recorded using a $2 \times 2$-in. $(5-\mathrm{cm} \times 5-\mathrm{cm})$ wel1-type NaI detector. The spectra indicated that the bulk of the protactinium in solution was being extracted in the solvent extraction step and then was being stripped by the carbonate stripping solution. Separation of the solid portion of the carbonate strip solution and counting showed the protactinium to be mainly in the solids. The ionium appeared to be extracted also but wound up in the liquid portion of the carbonate strip solution, which agrees with the previous results.?

Protactinium analyses were made on a number of the samples by the diisobutyl carbinol extraction method reported previously, ${ }^{2}$ and the results are given in Table 3 along with a calculated daily throughput. Comparison with previous protactinium analyses showed the content of both the feed residue and the feed solution to be roughly half that of the first samples, and is probably due to inhomogeneities in the feed residue. The values for the feed solution and the aqueous raffinate indicate that nearly $90 \%$ of the protactinium was extracted, and this is much higher than observed previously. The results on the two phases of the pregnant carbonate solution confirm that most of the protactinium is to be found in the solids. The total protactinium found at this point was lower than expected, probably because of inadequacy or problems of sampling.

These results indicate that a good yield of protactinium could be obtained by filtering the solids from the pregnant carbonate stream. Although ionium analyses were not performed, the gamma spectra and other evidence indicated that there was little change of chemistry from that of the previous samples. At that time it was shown that most of the ionium wound up in the supernatant portion of the pregnant carbonate solution. 
Table 2

SAMPLES FROM COTTER CORPORATION RECOVERY PROCESS

Sample

Number

Description

COT-21 Aqueous slurry of St. Louis residues after ball milling and just prior to leaching. Dried before analysis.

COT-22 Acid Leached Residue--Solids remaining after leaching and washing which are sent to tailings area. Dried before analysis.

COT-23 Acid Leach Liquor--The sulfuric acid leach liquor which is the liquid feed for the rest of the process.

COT-24 Pregnant Organic--The organic extractant containing the extracted uranium. Probably a mixture of di-2-ethylhexyl phosphoric acid and dibutyl butyl phosphonate in a kerosene diluent.

COT-25 Raffinate solution after the extraction step.

COT-26 Selenium Concentrate--A moist, dark cake which appears similiar to the other sulfide concentrates. Dried before analysis.

COT-27 Pregnant Carbonate--The sodium carbonate strip of the solvent extraction step, containing uranium and iron. The solids from this sample were separated and analyzed separately. (COT-27A Supernatant solution)

(COT-27B Dissolved solids)

COT-28 Interface Crud from Carbonate Stripping--This sample was separated into three phases: organic, carbonate, and solids.

COT-29 Interface Crud from Extraction--A little organic material but mostly a black solid.

COT-30 Stripped Organic--Organic phase after stripping with carbonate solution.

Negotiations with Cotter are under way to separate protactinium and ionium from the pregnant carbonate stream. Five drums of protactiniumrich crud material have been obtained from Cotter. 
Table 3

PROTACTINIUM ANALYSES OF COTTER SAMPLES

\begin{tabular}{|c|c|c|c|}
\hline $\begin{array}{l}\text { Sample } \\
\text { Number } \\
\end{array}$ & Type & $\begin{array}{l}\text { Protactinium- } \\
231 \text { Found } \\
\end{array}$ & $\begin{array}{c}\text { Throughput } \\
\text { (g/day) }\end{array}$ \\
\hline $\mathrm{COT}-21$ & Feed Residue & $12 \mathrm{ppb}$ & 0.79 \\
\hline $\mathrm{COT}-22$ & Insoluble Residue & $5 \mathrm{ppb}$ & 0.16 \\
\hline $\mathrm{COT}-23$ & Feed Solution & $3.6 \mu \mathrm{g} / 1$ iter & 0.98 \\
\hline $\mathrm{COT}-25$ & Aqueous Raffinate & $0.38 \mu \mathrm{g} / 1$ iter & 0.10 \\
\hline $\mathrm{COT}-26$ & Selenium Product & $15 \mathrm{ppb}$ & 0.001 \\
\hline $\operatorname{COT}-27 \mathrm{~A}$ & Pregnant Carbonate (Supernatant) & $0.95 \mu \mathrm{g} / 1$ iter & 0.02 \\
\hline $\mathrm{COT}-27 \mathrm{~B}$ & Pregnant Carbonate (Solids) & $(11 \mu g / 1 \text { iter })^{2}$ & 0.23 \\
\hline
\end{tabular}




\title{
Inorganic Chemistry
}

\author{
A NEW SAMARIUM HYDRIDE
}

One of the unexpected developments in the chemistry of the lanthanide elements in recent years is the discovery of curious series of hydrides. ${ }^{3-4}$ These hydrides may be prepared by the uncomplicated process of dissolving an elemental lanthanide in a warm solution of several acids. ${ }^{5}$ Dilute (e.g., 1M) solutions have been used for this preparation, although no confirmation has ever been presented that this particular acidity gives the maximum yield of the rare earth product.

A new samarium hydride has been prepared by dissolving elemental samarium in a warm $\left(80^{\circ} \mathrm{C}\right)$ solution consisting of two parts, by volume, of water and one part, by volume, of $\mathrm{HC}_{2} \mathrm{H}_{3} \mathrm{O}_{2}$. This acid solution gave a much higher yield of the new samarium compound (which separated as a yellow precipitate) than did $1 \mathrm{M} \mathrm{HC}_{2} \mathrm{H}_{3} \mathrm{O}_{2}$, suggesting that study of the acid concentration and temperature which maximizes the yield of these rare earth hydrides would be interesting and useful. Such a study has never been made. The compound was washed with acetone and dried in vacuum over $\mathrm{P}_{2} \mathrm{O}_{5}$ and $\mathrm{KOH}$. The $\mathrm{x}$-ray powder pattern of the new samarium compound, shown in Table 4, indicates that the structure of this compound is very similar to that of analogous rare earth compounds. This similarity is further illustrated in Figure 2, which shows a plot of a principal lattice parameter (the $d$-spacing represented by the most intense $x$-ray line observed in the powder pattern) as a function of atomic number for several selected new lanthanide hydrides. The acids used include acetic $\left(\mathrm{CH}_{3} \mathrm{COOH}\right)$, propiolic $(\mathrm{HCCCOOH})$, and mucochloric (CHOCCICClCOOH). The selections were based upon estimated "purity" of the product (i.e., the probable extent of contamination with the normal trivalent lanthanide salt of the acid used). That the new samarium compound is a hydride was not proven but was assumed by analogy with similar compounds. From Figure 2 it can be seen that the d-spacing decreases rather uniformly with increasing atomic number, perhaps an unusual illustration of the "lanthanide contraction." The fluorite-type structure suggested by Table 4 is characteristic of $\mathrm{SmH}_{2}$, but it seems unlikely that this compound could separate from a water solution since $\mathrm{LnH}_{2}$-type hydrides are reported to be readily attacked by water. ${ }^{5}$ An attempt to prepare the analogous europium compound was not successful. 


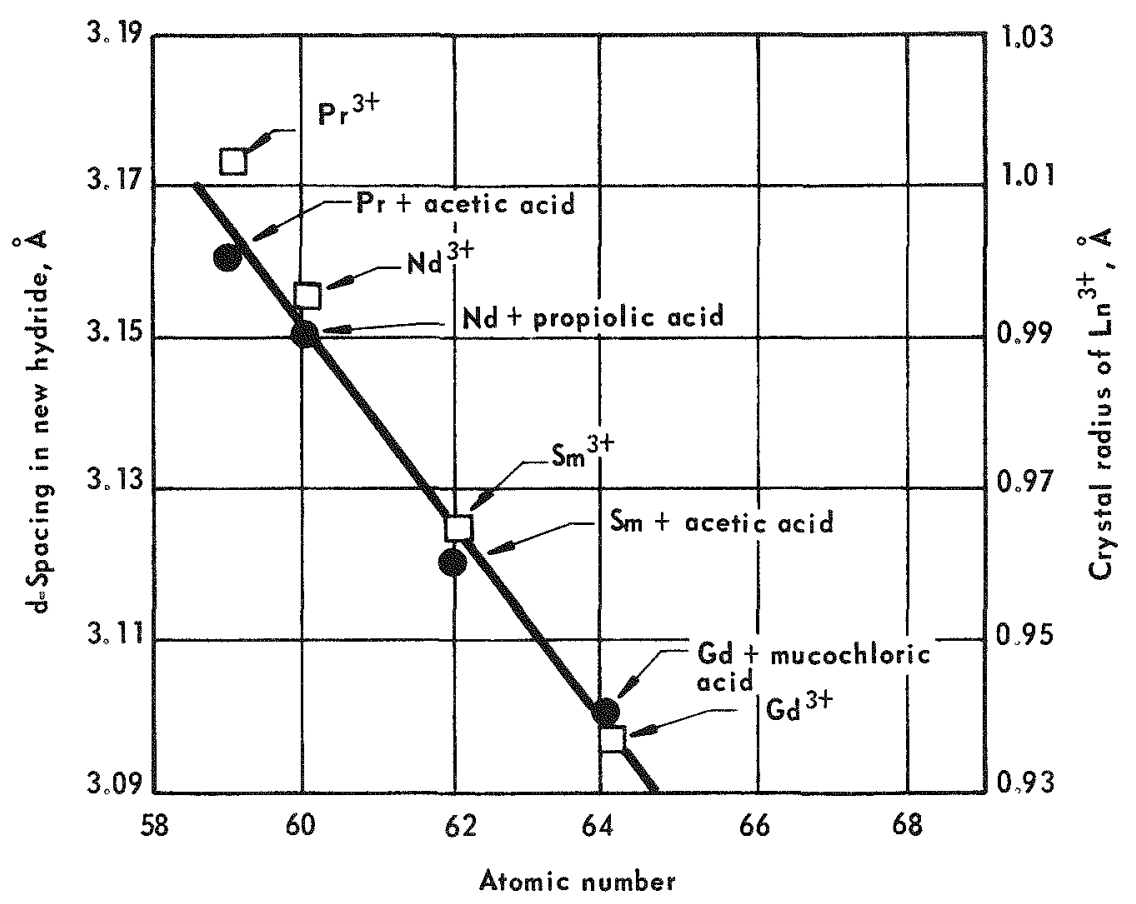

FIGURE 2 - Plot of d-spacings and crystal radii as a function of atomic number.

Table 4

\section{$X$-RAY POWDER PATTERN OF COMPOUND PREPARED BY DISSOLVING SAMARIUM IN A WARM ACETIC ACID \\ SOLUTION}

$d-$ Spacing
$(\AA)$

3. 1241

2.7013

1.9203

1. 6402

1. 6203

1. 5676

1. 3663

1. 2482

1. 2187

1. 1091

1. 0444
Relative Intensity (arbitrary units)

10

6

7

7

2

3

2

4

4

5

4 
Samples of the new samarium compound were placed in x-ray capillary tubes in the hope of obtaining powder patterns of the material up to $600^{\circ} \mathrm{C}$. Unfortunately, every capillary tube exploded either during heating or during cooling after being withdrawn from the furnace, probably due to internal pressure of released hydrogen gas. One capillary heated to $600^{\circ} \mathrm{C}$ still retained enough material for an $\mathrm{x}$-ray powder pattern even after it exploded. This pattern is shown in Table 5. Some of the lines are suggestive of europium (II) oxide. Since these new rare earth hydrides contain oxygen and a powerful reducing agent (the hydride anion) as an intrinsic part of their structure, it would appear that these new compounds might serve as excellent starting materials for the preparation of samarium (II) oxide or ytterbium (II) oxide." Curiously, the new samarium hydride darkened somewhat as it was heated, but the light color returned near $600^{\circ} \mathrm{C}$. Table 5 indicates that the product of pyrolysis at $600^{\circ} \mathrm{C}$ was not $\mathrm{Sm}_{2} \mathrm{O}_{3}$.

Elementa1 analysis of the compound indicated $9.44 \%$ carbon and $2.04 \%$ hydrogen. The samarium content of the material could not be determined. (G. L. Silver)

Table 5

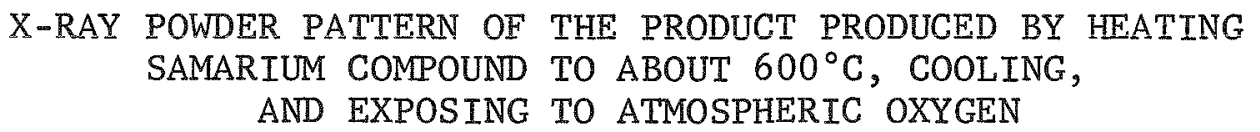

\begin{tabular}{c}
$\begin{array}{c}d-\text { Spacing } \\
(\AA)\end{array}$ \\
\hline 3.3733 \\
3.2879 \\
3.1085 \\
2.8213 \\
2.7092 \\
2.5558 \\
2.1221 \\
2.0402 \\
1.9569 \\
1.9218 \\
1.8450 \\
1.7494 \\
1.6839 \\
1.6410 \\
1.6082 \\
1.5635 \\
1.3445 \\
1.2814 \\
1.2484 \\
1.2163 \\
1.1163
\end{tabular}

Relative Intensity (arbitrary units) 


\section{ENTROPY FUNCTIONS FOR SOME IONS OF} URANIUM, NEPTUNIUM AND PLUTONIUM

In a recent article, strong and Halliwe $11^{8}$ have described the advantages of using the Planck Function in place of the Gibbs Free Energy Function. In Figure 3 are plotted the terms which constitute this function, the energy distribution term (system entropy) $\Delta S_{s}$, and the environmental entropy term $\Delta S_{e}$ for ions derived from uranium, neptunium and plutonium. From this diagram it would appear that the chemistry of the ions $\mathrm{UO}_{2}{ }^{*}$, $\mathrm{NpO}_{2}{ }^{+}$and $\mathrm{PuO}_{2}+$ might be very similar, since differences in the ions are, apparently, largely due to the environmental entropy term and not the system entropy term. Interestingly, the ions vary in a systematic manner: neptunium always occurs between uranium and plutonium. Experience shows, however, that $\mathrm{NpO}_{2}{ }^{+}$is much less susceptible to partitioning into the tetravalent and hexavalent states than are $\mathrm{UO}_{2}{ }^{+}$and $\mathrm{PuO}_{2}{ }^{+}$ions, although this is not suggested by Figure 3 .

In Figure 4 are plotted the environmental and system entropy terms for the reaction

$$
2 \mathrm{MO}_{2}^{+}+4 \mathrm{H}^{+}=\mathrm{M}^{4+}+\mathrm{MO}_{2}^{2+}+2 \mathrm{H}_{2} \mathrm{O} \quad \mathrm{K}=\mathrm{K}
$$

where $\mathrm{M}$ is $\mathrm{U}$, Np or $\mathrm{Pu}$. Figure 4 shows that uranium and plutonium in the pentavalent state are more alike than are uranium and neptunium or plutonium and neptunium (in agreement with experience), that the large difference between neptunium and adjacent actinides is due primarily to differences in meta1-oxygen bond energies (including hydration bond energies), and that the energy distribution changes for the disproportionation Reaction 1 are about equa1. For Figures 3 and 4, data for plutonium were taken from Reference 9 and for uranium and neptunium from Reference 10 (circles).

Figure 5 presents entropy terms for the reaction

$$
\mathrm{M}^{4+}+\mathrm{MO}_{2}^{+}=\mathrm{MO}_{2}^{2+}+\mathrm{M}^{3+}
$$

From this plot it can be seen that the monotonic behavior of uranium, neptunium and plutonium is interrupted and that uranium now falls between plutonium and neptunium. Both are significantly different from plutonium, however, and this difference is apparently due largely to differences in meta1-oxygen bond energies. In Figure 6 is presented a graphical sum (i.e., the vector sum) of the entropy terms for the reactions above according to the scheme

$$
3 \mathrm{M}^{4+}+2 \mathrm{H}_{2} \mathrm{O}=2 \mathrm{M}^{3+}+\mathrm{MO}_{2}^{2+}+4 \mathrm{H}^{+}
$$




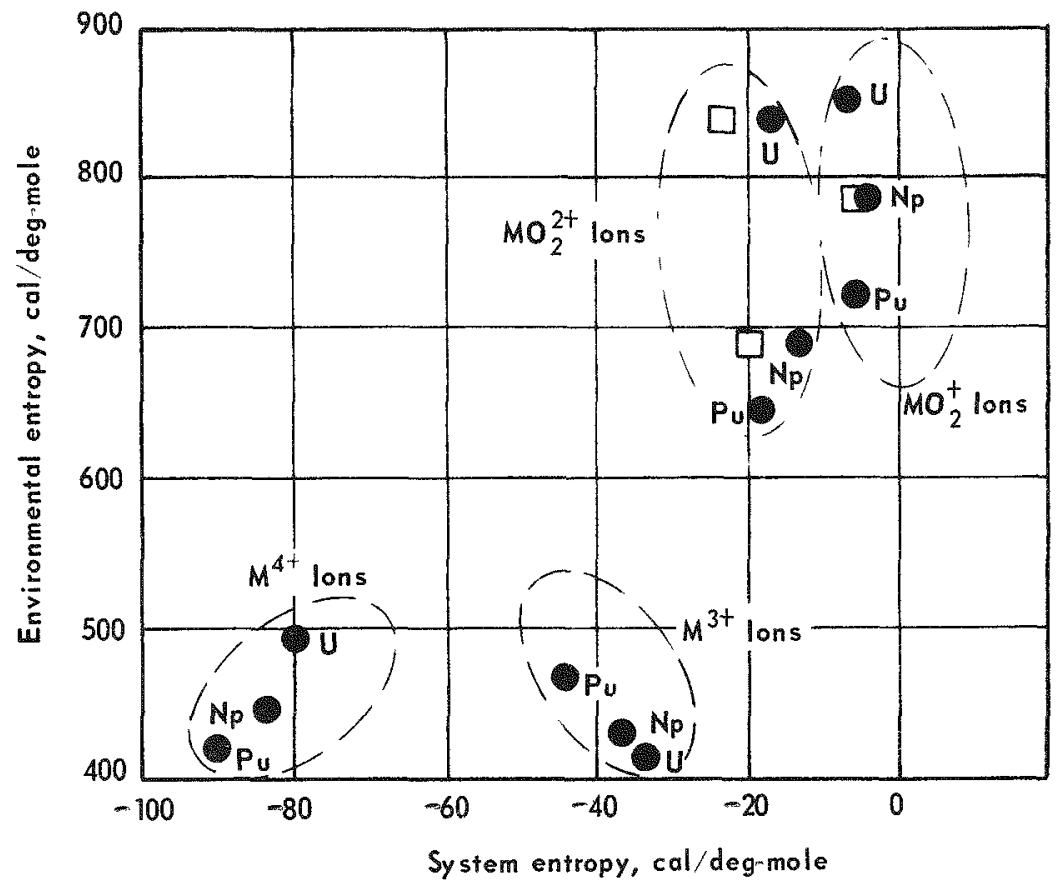

FIGURE 3 - Entropies of some actinide ions.

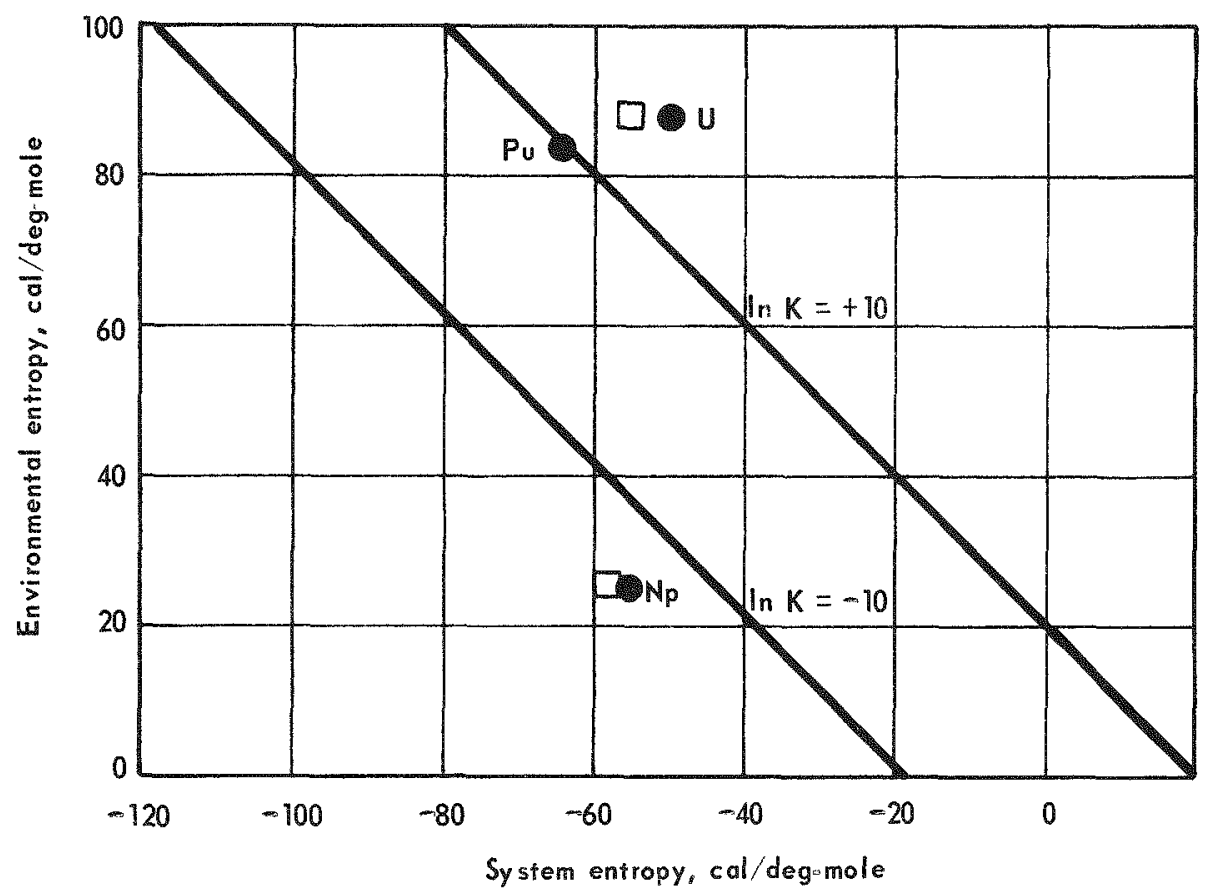

FIGURE 4 - Entropy terms for the function described by reaction 1. 


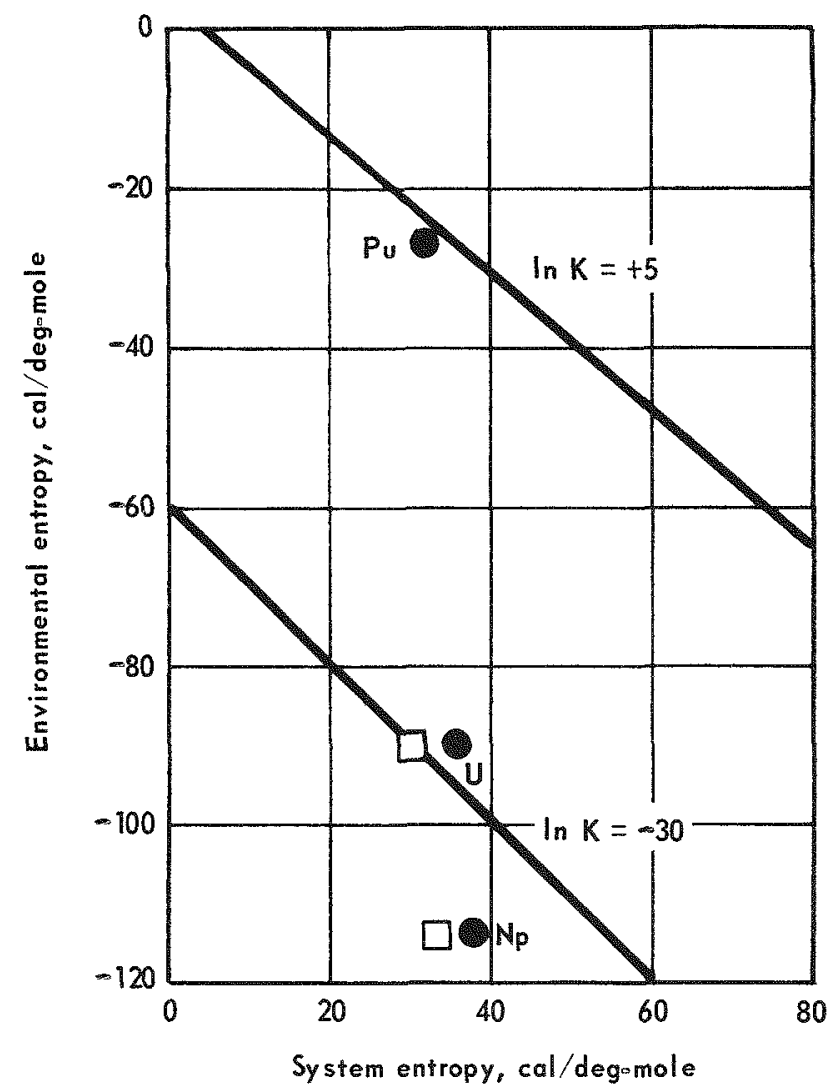

FIGURE 5 - Entropy terms for the function described by reaction 2 .

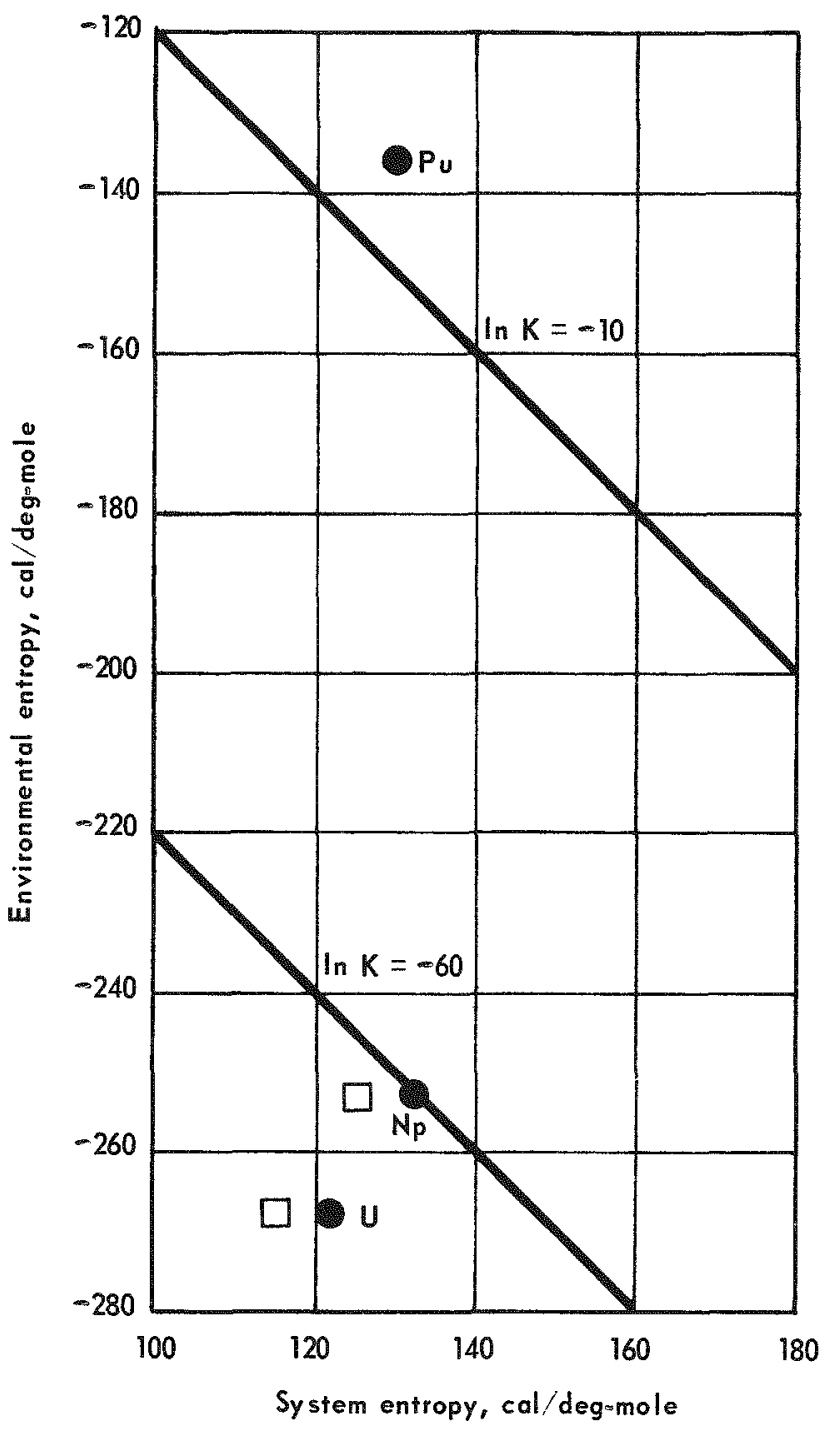

FIGURE 6 - Entropy terms for the function described by reaction 3 as obtained by graphical addition of Figures 4 and 5 .

or

$$
\begin{array}{ll}
\mathrm{M}^{4+}+\mathrm{MO}_{2}{ }^{2+}+2 \mathrm{H}_{2} \mathrm{O}=2 \mathrm{MO}_{2}^{+}+4 \mathrm{H}^{+} & \Delta \mathrm{S}=-\Delta \mathrm{S}_{1} \\
\frac{2 \mathrm{M}^{4+}+2 \mathrm{MO}_{2}^{+}=2 \mathrm{MO}_{2}^{2+}+2 \mathrm{M}^{3+}}{3 \mathrm{M}^{4+}+2 \mathrm{H}_{2} \mathrm{O}=2 \mathrm{M}^{3+}+\mathrm{MO}_{2}{ }^{2+}+4 \mathrm{H}^{+}} & \frac{\Delta \mathrm{S}=2 \Delta \mathrm{S}_{2}}{\Delta \mathrm{S}_{3}=2 \Delta \mathrm{S}_{2}-\Delta \mathrm{S}_{1}}
\end{array}
$$

From Figure 6 it can be seen that the tendency of $\mathrm{M}^{4}+$ to partition into $\mathrm{M}^{3+}$ and $\mathrm{MO}_{2}{ }^{2+}$ is greatest for plutonium and much less for uranium and 
neptunium, this tendency again being influenced primarily by bond energy considerations.

In Figure 7 are shown entropy terms for the reaction

$$
2 \mathrm{M}^{4}+2 \mathrm{H}_{2} \mathrm{O}=\mathrm{MO}_{2}^{+}+\mathrm{M}^{3+}+4 \mathrm{H}^{+}
$$

obtained by adding graphically Figure 3 and Figure 4 according to the scheme:

$$
\begin{array}{ll}
\mathrm{M}^{4+}+\mathrm{MO}_{2}^{2+}+2 \mathrm{H}_{2} \mathrm{O}=2 \mathrm{MO}_{2}^{+}+4 \mathrm{H}^{+} & \Delta \mathrm{S}=-\Delta \mathrm{S}_{1} \\
\frac{\mathrm{M}^{4+}+\mathrm{MO}_{2}^{+}=\mathrm{MO}_{2}^{2+}+\mathrm{M}^{3+}}{2 \mathrm{M}^{+}+2 \mathrm{H}_{2} \mathrm{O}=\mathrm{MO}_{2}^{+}+\mathrm{M}^{3+}+4 \mathrm{H}^{+}} & \frac{\Delta \mathrm{S}=\Delta \mathrm{S}_{2}}{\Delta \mathrm{S}_{4}=\Delta \mathrm{S}_{2}-\Delta \mathrm{S}_{1}}
\end{array}
$$

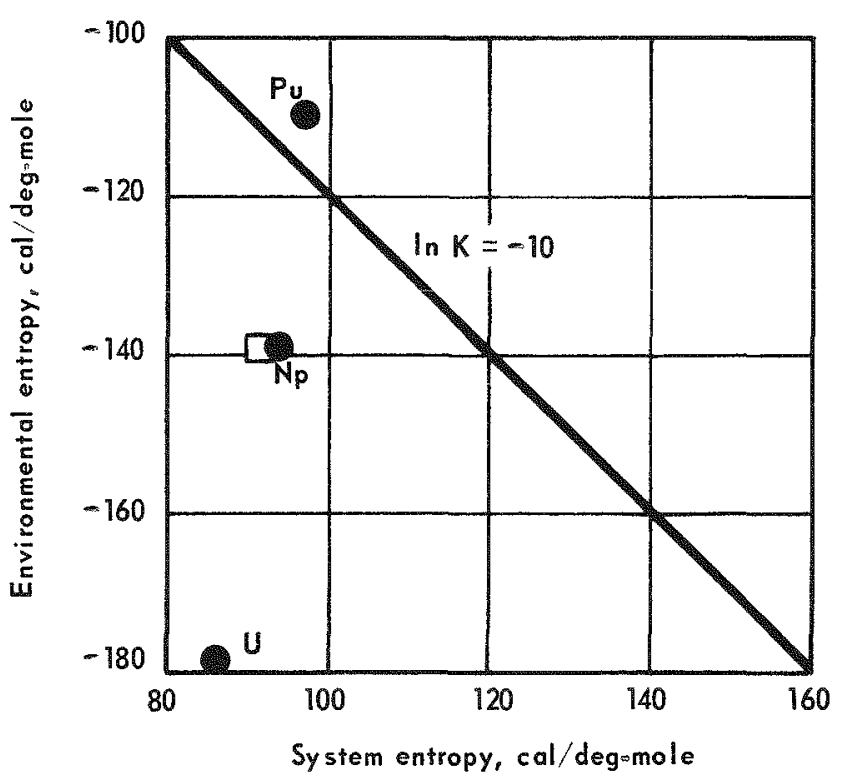

FIGURE 7 - Entropy terms for the function described by reaction 4 as obtained by graphical addition of Figures 4 and 5 .
From Figure 7 it can be seen that $\mathrm{Pu}^{4}+$ has the largest tendency to partition into $\mathrm{M}^{3+}$ and $\mathrm{MO}_{2}{ }^{+}$, and that neptunium occurs almost halfway between uranium and plutonium but is somewhat closer to plutonium than to uranium.

More recent values of the entropies of actinide ions are probably more reliable, ${ }^{11}$ but these values change the locus of points in Figures 3 to 7 by sma 11 amounts on $1 y$. Where significant, such changes as the data in Reference 11 might cause are shown in Figures 3 to 7 by small squares. Only data points reflecting uncertainties in the entropies of the oxygenyl cations of uranium and neptunium are affected. (G. L. Silver) 


\title{
Analytical Chemistry
}

\author{
DETERMINATION OF PLUTONIUM IN SOIL
}

A complete procedure has been established for the determination of plutonium in soil by a fusion technique. The results obtained by this method will be compared to the results previously obtained by the acid-leach technique. 12

To obtain fairly reproducible recovery of the plutonium in the electrodeposition step, the electrolysis cell is immersed in a cold water bath so that the electrolyte temperature is held constant at approximately $30^{\circ} \mathrm{C}$. The voltage is held constant at $8 \mathrm{~V}$, while the current is maintained at 1.4-1.5 A (current density $\cong 0.75 \mathrm{~A} / \mathrm{cm}^{2}$ ) by adjusting the distance between the platinum gauze anode and the stainless stee 1 disc cathode. A plating time of $75 \mathrm{~min}$ is being used.

To qualify any errors due to less-than-100\% recovery of plutonium, plutonium-236 tracer is added to the soil samples before the fluoride fusion. (The daughter nuclides from the plutonium-236 tracer solution were previously removed by an anion exchange separation.)

The low specific activity of the plutonium-236 tracer solution was difficult to determine accurately by proportional or liquid scintillation counting. Therefore, an indirect method of determination was used. Two milliliters of the plutonium-236 solution were mixed with $1 \mathrm{~m} 1$ of a plutonium-238 solution $(19,300 \mathrm{dis} / \mathrm{min} / \mathrm{ml}$ as determined by 1 iquid scintillation counting). The plutonium was then electrodeposited on a slide, and the ${ }^{236} \mathrm{Pu} / 238 \mathrm{Pu}$ ratio was determined by alpha pulse height analysis. The background in the plutonium-236 energy range with the surface barrier detector was practica11y zero. The disintegration rate of the plutonium-236 was calculated from the isotopic ratio and disintegration rate of the plutonium-238, and was found to be $3.23 \pm 0.06$ $\mathrm{dis} / \mathrm{min} / \mathrm{m} 1$ on November $10,1970$.

Several blank determinations were made to examine the possibility of contamination of the reagents or glassware. A plutonium-236 tracer was added to all the blanks and carried through the entire procedure as a check on percent recovery. The results are expressed in Table 6 as disintegrations per minute of plutonium-238, disintegrations per minute of plutonium-239, and percent recovery of the plutonium-236 
tracer. The error limit given for the individual determinations is based solely on counting statistics. The error limit given for the average value is the experimental standard deviation. Al1 figures are raw data, with no corrections made for the disintegration rate figures in view of the percent of plutonium-236 tracer recovered.

Four soil samples have been analyzed by the fusion procedure and the results for the disintegration rates for plutonium-238 and plutonium-239 are given, along with the percent recovery of the plutonium-236 tracer, in Table 7. All disintegration rates are given on a relative basis. The average plutonium-238 disintegration rate for sample A was arbitrarily set at $100 \mathrm{dis} / \mathrm{min} / \mathrm{g}$. A11 other rates for plutonium-238 and plutonium-239 are reported relative to the value determined for Sample A. The error limit given for individual determinations is based solely on counting statistics. The error limit given for the average value is the experimental standard deviation. Ten-gram soil samples were analyzed in each case, and the disintegration rates have been corrected for recovery of the plutonium-236 tracer. The experimental standard deviation for the lowest level sample of plutonium-238 is of the same order of magnitude as the error limit given for counting statistics. As the amount of plutonium in the sample increased, the experimental standard deviation became much higher than the error limit given for counting statistics.

Table 6

\begin{abstract}
RESULTS OF BLANK DETERMINATIONS FOR REAGENTS AND GLASSWARE CONTRIBUTTON TO SAMPLE CONTAMINATION
\end{abstract}

\begin{tabular}{|c|c|c|c|}
\hline $\begin{array}{l}\text { Blank } \\
\text { Number }\end{array}$ & $\begin{array}{c}2{ }^{8} \mathrm{Pu} \text { Counted } \\
\text { (dis/min) }\end{array}$ & $\begin{array}{c}2{ }^{39} \mathrm{Pu} \text { Counted } \\
\text { (dis/min) }\end{array}$ & $\begin{array}{c}\text { Recovered } \\
(\%)\end{array}$ \\
\hline 1 & $0.0399 \pm 0.0182$ & $0.0044 \pm 0.0061$ & $33.3 \pm 1.7$ \\
\hline 2 & $0.0596 \pm 0.0212$ & $0.0125 \pm 0.0083$ & $31.2 \pm 1.6$ \\
\hline 3 & $0.0273 \pm 0.0188$ & $0.0078 \pm 0.0075$ & $12.3 \pm 1.1$ \\
\hline 4 & $0.0187 \pm 0.0159$ & $0.0015 \pm 0.0044$ & $15.7 \pm 1.1$ \\
\hline 5 & $0.0228 \pm 0.0170$ & $0.0152 \pm 0.0090$ & $45.7 \pm 2.1$ \\
\hline 6 & $0.0756 \pm 0.0248$ & $0.0079 \pm 0.0076$ & $42.1 \pm 2.1$ \\
\hline Average & $0.0407 \pm 0.0226$ & $0.0082 \pm 0.0050$ & $30.1 \pm 13.6$ \\
\hline $\begin{array}{l}\text { Re1. Std. } \\
\text { Dev. }\end{array}$ & $\pm 55.7 \%$ & $\pm 61.4 \%$ & $\pm 45.2 \%$ \\
\hline
\end{tabular}


Table 7

PLUTONIUM DISINTEGRATION RATES AND TRACER RECOVERIES FOR SOIL SAMPLES

\begin{tabular}{|c|c|c|c|}
\hline $\begin{array}{l}\text { Sample } \\
\text { Number }\end{array}$ & $\begin{array}{c}\text { Plutonium-238 } \\
\text { in Sample } \\
\text { (Corrected for } \\
\text { Tracer Recovery) } \\
\text { (relative dis/min/g) }\end{array}$ & $\begin{array}{c}\text { Plutonium-239 } \\
\text { in Sample } \\
\text { (Corrected for } \\
\text { Tracer Recovery) } \\
\text { (relative dis/min/g) }\end{array}$ & $\begin{array}{c}\text { P1utonium-236 } \\
\text { Tracer } \\
\text { Recovered } \\
(\%) \\
\end{array}$ \\
\hline$A-1$ & 44.21 & $0.3340 \pm 0.0492$ & $86.2 \pm 4.8$ \\
\hline$A-2$ & $63.79 \pm 3.27$ & $0.3101 \pm 0.0404$ & $84.0 \pm 4.1$ \\
\hline$A-3$ & $43.40 \pm 2.39$ & $0.2786 \pm 0.0412$ & $86.9 \pm 4.5$ \\
\hline$A-$ & $44.90 \pm 2.35$ & $0.3355 \pm 0.0423$ & $92.8 \pm 4.5$ \\
\hline$A-$ & \pm 12.97 & $0.6614 \pm 0.1932^{\circ}$ & $89.2 \pm 4.4$ \\
\hline$A-6$ & \pm 5.23 & $0.6029 \pm 0.0631$ & $75.2 \pm 3.8$ \\
\hline$A-7$ & \pm 2.27 & $0.3832 \pm 0.0539$ & $75.6 \pm 4.2$ \\
\hline$A-8$ & \pm 14.16 & $1.0050 \pm 0.2174^{\mathrm{a}}$ & $63.3 \pm 4.0$ \\
\hline$\overline{\text { Avera }}$ & $100.00 \pm 85.39^{b}$ & $0.4888 \pm 0.2519$ & $81.7 \pm 9.6$ \\
\hline
\end{tabular}

Rel. Std.

Dev.

$\pm 85.4 \%$

$\pm 51.5 \%$

$\pm 11.8 \%$

\begin{tabular}{llllll}
$\mathrm{B}-1$ & $6.726 \pm 0.292$ & & $0.2924 \pm 0.0269$ & $80.7 \pm 3.0$ \\
$\mathrm{~B}-2$ & $7.907 \pm 0.331$ & & $0.3224 \pm 0.0273$ & $81.6 \pm 2.9$ \\
$\mathrm{~B}-3$ & $5.425 \pm 0.227$ & & $0.2870 \pm 0.0246$ & $81.2 \pm 2.9$ \\
$\mathrm{~B}-4$ & $5.164 \pm 0.239$ & & $0.3713 \pm 0.0327$ & $73.1 \pm 2.8$ \\
$\mathrm{~B}-5$ & $5.306 \pm 0.239$ & & $0.3294 \pm 0.0296$ & \\
\cline { 3 - 5 } Average & $6.106 \pm 1.185$ & $0.3205 \pm 0.0338$ & $\frac{76.6 \pm 2.9}{78.6 \pm 3.7}$
\end{tabular}

Re1. Std.

Dev.

$\pm 19.4 \%$

$\pm 10.6 \%$

$\pm 4.7 \%$

\begin{tabular}{ccccc}
$C-1$ & $0.7799 \pm 0.0323$ & $0.1781 \pm 0.0112$ & $54.3 \pm 1.5$ \\
$C-2$ & $0.6322 \pm 0.0508$ & $0.1958 \pm 0.0250$ & $57.5 \pm 2.4$ \\
$C-3$ & $0.5548 \pm 0.0254$ & $0.2005 \pm 0.0123$ & $71.1 \pm 2.0$ \\
C-4 & $0.7153 \pm 0.0512$ & $0.2224 \pm 0.0246$ & \\
\cline { 2 - 5 } & $0.6706 \pm 0.0980$ & $0.1992 \pm 0.0182$ & & $\frac{70.4 \pm 2.7}{63.3 \pm 8.7}$
\end{tabular}

Re1. Std.

Dev.

$\pm 14.6 \%$

$\pm 9.2 \%$

$\pm 13.7 \%$

\begin{tabular}{llll} 
D-1 & $0.1978 \pm 0.0319$ & $0.0896 \pm 0.0196$ & $57.5 \pm 3.5$ \\
D-2 & $0.1293 \pm 0.0123$ & $0.0827 \pm 0.0088$ & $71.4 \pm 2.5$ \\
D-3 & $0.1427 \pm 0.0242$ & $0.0677 \pm 0.0150$ & $56.2 \pm 3.1$ \\
D-4 & $0.1401 \pm 0.0296$ & $0.1077 \pm 0.0231$ & $42.3 \pm 2.8$ \\
\hline Average & $0.1525 \pm 0.0308$ & $0.0869 \pm 0.0166$ & $56.9 \pm 11.9$
\end{tabular}

Re1. Std.

Dev.

$\pm 20.2 \%$

$\pm 19.1 \%$

$\pm 20.9 \%$

${ }^{a}$ Counting efficiency $4.2 \%$; a 11 others at $17.0 \%$.

${ }^{b}$ Average of Sample $A$ is arbitrarily set at $100 \mathrm{dis} / \mathrm{min} / \mathrm{g}$. 
This probably indicates nonuniform distribution of plutonium in the samples containing a larger amount of plutonium. It is suspected that the plutonium is concentrated in a few sma11 particles so that even multiple riffling of a large sample would not necessarily produce smaller samples of the same plutonium composition.

Samples A-5 and A-8 contained much more plutonium-238 than plutonium-239, and the plutonium-239 could not be determined with the $17 \%$ counting efficiency. A lower counting geometry was utilized to get better resolution of the plutonium-239 photopeak from the plutonium-238 photopeak. The counting efficiency for this lower counting geometry was $4.2 \%$.

A "plutonium-soil-sample" standard prepared by C. W. Sill (Health Services Laboratory, U. S. Atomic Energy Commission, Idaho Fa11s, Idaho) was analyzed in duplicate by the fusion procedure. The results of this analysis are given in Table 8 . Such good agreement indicates accuracy in the fusion method of soil analysis. The error limit given for each individual determination is based solely on counting statistics.

Table 8

PLUTONIUM DISINTEGRATION RATE AND TRACER RECOVERY FOR A "PLUTONIUM-SOIL-SAMPLE" STANDARD

\begin{tabular}{|c|c|c|c|}
\hline $\begin{array}{l}\text { Sample } \\
\text { Number }\end{array}$ & $\begin{array}{c}\text { Plutonium-239 } \\
\text { in Sample } \\
\text { (Standard Value) } \\
\text { (dis/min/g) } \\
\end{array}$ & $\begin{array}{c}\text { Plutonium-239 } \\
\text { in Sample } \\
\text { (Found) } \\
\text { (dis/min/g) } \\
\end{array}$ & $\begin{array}{c}\text { P1utonium-236 } \\
\text { Tracer } \\
\text { Recovered } \\
(\%) \\
\end{array}$ \\
\hline Sil1-1 & 35.42 & $33.48 \pm 1.67$ & $50.7 \pm 2.3$ \\
\hline Si11-2 & 35.42 & $35.26 \pm 1.49$ & $57.4 \pm 2.2$ \\
\hline Average & 35.42 & 34.37 & 54.1 \\
\hline
\end{tabular}

A standard plutonium soil sample spiked with plutonium-238 will be prepared similarly to the one prepared by si11. This homogeneous soil sample will then be used to determine the precision of the fusion method. Soil residues that have been analyzed by the acid-leach procedure will be determined by the fusion procedure to determine the loss, if any, in the leach step. (C. T. Bishop, M. M. Bolton, M. L. Curtis, J. O. Frye, R. K. Gillette and E. B. Nunn) 


\section{EVALUATION OF THE PORTABLE GAMMA-MEASURING TECHNIQUE FOR DETERMINING PLUTONIUM-238 IN GLOVEBOXES}

A building termination program requires periodic determination of plutonium-238 contained in gloveboxes being cleaned for subsequent removal from the building. A portable and rapid technique was developed for measuring gross gamma-radiation, approximately $75 \mathrm{keV}$ and greater, originating from individual boxes as they exist in a box line.

Major problems exist with determining correct background values, variations in material configuration, and box equipment attenuation of the radiation. Large biases are evident when results determined by this procedure and results determined by can assay of material after remova 1 from the terminated box are compared. Table 9 indicates a negative $41 \%$ bias in the portable technique compared to can assay. Can assay is capable of measuring with an uncertainty of $\pm 18 \%$ at the $95 \%$ confidence leve1. $13-14$

Biases also exist between final portable scan results and the results obtained by the $760-\mathrm{keV}$ gamma energy assay of the crated box after removal from the building. Table 10 indicates a negative $60 \%$ bias in the portable technique compared to crate assay. Crate assay is capable of measuring with an estimated uncertainty of $\pm 60 \%$ at the $90 \%$ confidence leve1.14

Because of the poor precision and negative bias experienced with the portable assay method, an investigation of an alternate technique was conducted. Instead of the standard technique of assaying a hood face from only one predetermined position, it was decided to utilize a portable crate scanning technique in which the entire face was scanned for "hot spots" in an attempt to pinpoint material locations. Two hoods and two hood wells, which after extensive cleaning still contained accountable amounts of material according to the standard measuring technique, were scanned by the modified technique. When results by both techniques were compared, no difference existed for one hood and two hood wells. The single-position technique indicated $2.7 \mathrm{~g}$ and the modified technique indicated $5.0 \mathrm{~g}$ for the other hood. The only conclusion that can be made is that both techniques are comparable and that material is actually present in these boxes despite extensive cleaning.

Another technique investigated involved increasing the glovebox-todetector distance to avoid errors which occur when measuring from small source-to-detector distances. This technique could not be utilized because of background error. The instrument being used has limited directional capabilities and, as a result, background from adjacent boxes could not be eliminated.

Work is continuing toward developing a more precise technique for determining the plutonium-238 content of gloveboxes being terminated. New, 
Table 9

COMPARISON OF PORTABLE ASSAY TO CAN ASSAY

\begin{tabular}{|c|c|c|c|}
\hline Room No. & $\begin{array}{c}\text { Material Removed by } \\
\text { Can Assay } \\
(\mathrm{g}) \\
\end{array}$ & $\begin{array}{c}\text { Material Removed by } \\
\text { Portab1e Assay } \\
(\mathrm{g}) \\
\end{array}$ & $\begin{array}{c}\text { Difference from } \\
\text { Can Assay } \\
(\%) \\
\end{array}$ \\
\hline 10 & 9.86 & 11.9 & +21 \\
\hline 20 & 1.33 & 2.20 & +65 \\
\hline 21 & 14.64 & 0.92 & -94 \\
\hline $38(W)$ & 153.16 & 64.5 & -58 \\
\hline $39(1)$ & 67.67 & 73.2 & +8.2 \\
\hline $39(2)$ & 15.84 & 7.57 & -52 \\
\hline $58(\mathrm{~A})$ & 25.86 & 8.40 & -68 \\
\hline 61 & 7.03 & 1.59 & -77 \\
\hline RNR & 5.75 & 6.29 & $\begin{array}{r}+9.4 \\
\end{array}$ \\
\hline Total & 301.14 & 176.6 & -41 \\
\hline
\end{tabular}


Table 10

COMPARISON OF PORTABLE ASSAY TO CRATE ASSAY

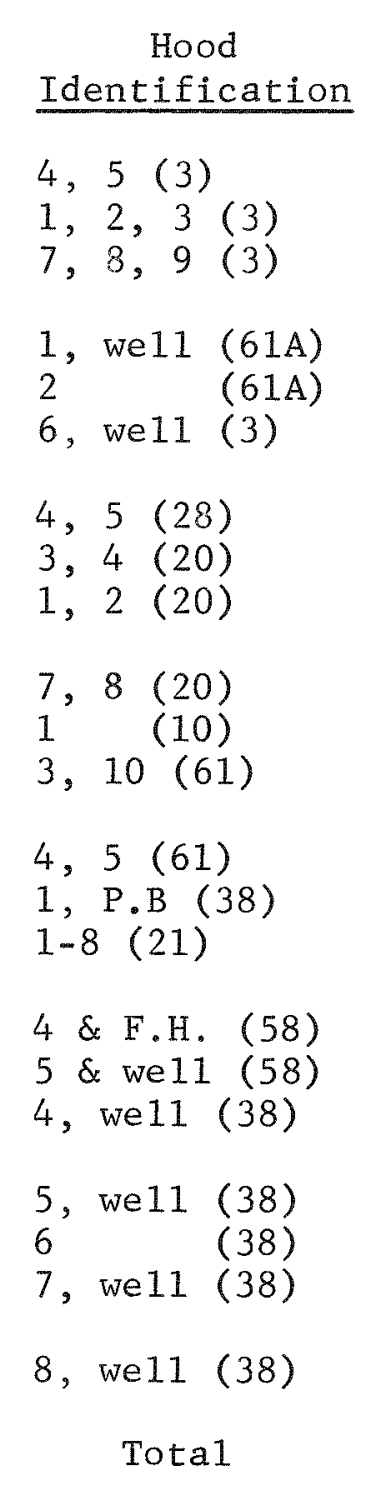

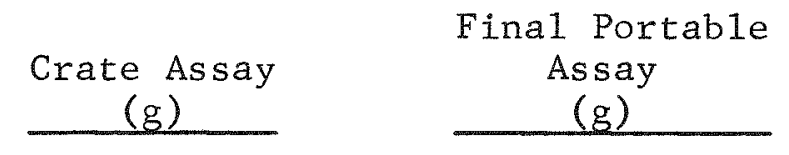

0.68

0.00

2.53

0.00

3.04

0.00

4.05

1.87

2.71

0.00

2.72

0.00

1.47

1.50

2.60

1.20

5.70

3.90

2.60

2.65

3.40

4.10

46.72
0.78

0.78

1.60

0.00

0.53

0.60

0.00

0.60

0.60

0.10

0.70

0.44

0.65

0.55

4.16

0.31

1.37

0.00

0.48

1.40

2.08

0.76

18.49
Difference from Crate Assay

$(\%)$

$+15$

$-37$

0
90

$-90$

$-100$

$-68$

$-78$

$-74$

$-56$

- 63

$+60$

$-74$

$-76$

$-100$

$-82$

$-47$

- 39

$-81$

$-60$ 
more reliable instrumentation has been investigated for possible application. A 2-in. $\times 2$-in. $(5-\mathrm{cm} \times 5-\mathrm{cm})$ NaI(T1) probe-type scintillation detector and portable single-channel analyzer system have been ordered for evaluation. With the new instrumentation and some modification in technique, attenuation and background problems should be reduced considerably. (D. C. Carter) 


\title{
Nuclear Physics
}

\author{
SPONTANEOUS FISSION HALF-LIFE OF PLUTONIUM-238
}

The experimental procedure and calculations for determination of the spontaneous fission half-life of $238 \mathrm{Pu}$ were described in a previous report. ${ }^{15}$ The spontaneous fission count rate from the source described above, containing 80 at. $\%{ }^{3} 38 \mathrm{Pu}$, has been corrected from $(185.9 \pm 6.9)$ $\times 10^{-4}$ counts/min to $(185.0 \pm 6.9) \times 10^{-4}$ counts/min. Using the values given in reference 15 and a value of $87.77 \pm 0.03 \mathrm{yr}$ as determined by K. C. Jordan of Mound Laboratory for the alpha half-life of ${ }^{238} \mathrm{Pu}$, the value of the spontaneous fission half-life of ${ }^{238} \mathrm{Pu}$ for this source was $4.79 \times 10^{10} \mathrm{yr}$.

A second source, having an isotopic composition of 99.48 at. $\% 238 \mathrm{Pu}$, gave a spontaneous fission count rate of $(183.6 \pm 6.5) \times 10^{-4}$ counts $/ \mathrm{min}$. Using a counting efficiency of $(1.59 \pm 0.01) \times 10^{-2}$, an alpha disintegration rate of $6.24 \times 10^{8} \mathrm{dis} / \mathrm{min}$ and the alpha half-life listed above, a spontaneous fission half-life value of $4.75 \times 10^{10}$ yr was obtained for this source.

Combining the data from both sources in which slightly greater than 800 counts were recorded from each source, the value of the spontaneous fission half-life of $238 \mathrm{Pu}$ was found to be $(4.77 \pm 0.14) \times 10^{10} \mathrm{yr}$. The uncertainty is given as one standard deviation $( \pm 1 \sigma)$. (J. D. Hastings and W. W. Strohm) 


\section{References}

1. Mound Laboratory Chemistry and Physics Progress Report: JulySeptember 1970, MLM-1767 (March 5, 1971), pp. 6-10.

2. Mound Laboratory Chemistry and Physics Progress Report: OctoberDecember 1970, MLM-1792 (June 30, 1971), pp. 8-12.

3. G. L. Silver, P. W. Seabaugh, W. H. Smith and R. R. Eckstein, Hydridic Nature of Rare Earth Preparations with Reducing Properties, MLM-1648 (August 8, 1969), 13 pp.

4. Mound Laboratory Chemistry and Physics Progress Report: April-June 1970, MLM-1751, (November 20, 1970), p. 11 .

5. G. L. Silver, J. Inorg. Nuc1. Chem., 30:7, 1735-8 (1968).

6. F. A. Cotton and G. Wilkinson, Advanced Inorganic Chemistry, 2nd Ed., Interscience, New York, 1966, p. 1059.

7. G. J. McCarthy, W. B. White and R. Roy, Proceedings of the Eighth Rare Earth Research Conference, April 19-22, 1970, Reno, Nevada, T. A. Henrie and R. E. Lindstrom (ed.), U. S. Department of the Interior and the Rare Earth Research Conference Committee, 1970, Vol. I, p. 366 .

8. L. E. Strong and H. F. Halliwe11, J. Chem. Ed., 47, 347 (1970).

9. G. L. Silver, Plutonium Disproportionation Reactions: Some Unresolved Problems, MIM-1807 (May 10, 1971), 56 pp.

10. V. M. Vdovenko, Chemistry of Uranium and Transuranium Elements, AEC-tr-6421 (September 1964), pp. 190-1, 244-7.

11. J. R. Brand and J. W. Cobble, Inorg. Chem., 9, 912-17 (1970)

12. MLM-1792, pp. 17-19. 
13. W. W. Strohm, A. B. Combs and J. Y. Jarvis, Gamma-Ray Assay of Plutonium-238 in Waste Cans, MLM-1585 (May 12,1969 ), p. 35.

14. W. W. Strohm, "Gamma-Ray Assay of the ${ }^{238} \mathrm{Pu}$ Content of Cans, 55-Gallon Drums and Crated Glove Boxes," presented at the Passive Gamma-Ray Seminar, Germantown, Maryland, November 19-20, 1970.

15. MLM-1792, pp. 24-25.

R. P. Ratay, Editor 